\title{
Fate of particle-bound bacteria ingested by Calanus pacificus
}

\author{
Sharon G. Lawrence ${ }^{1,2}$ Azeem Ahmad ${ }^{1}$, Farooq Azam ${ }^{1}$ \\ 'Marine Biology Research Division, Scripps Institution of Oceanography, University of California at San Diego, \\ La Jolla, California 92093-0202, USA \\ ${ }^{2}$ The Freshwater Institute, 501 University Crescent, Winnipeg, Manitoba, Canada R3T 2N6
}

\begin{abstract}
Bacteria bound to particles can be ingested by marine calanoid copepods, thus potentially providing a direct trophic link between bacteria and metazoa provided the microbes are digested by the animals. If some bacteria survive gut passage, they might play a role in fecal pellet solubilization and fragmentation (via ectoenzymes) and decomposition. We examined whether Calanus pacificus could assimilate bacterial biomass and whether a significant fraction of the ingested bacteria passed into the fecal pellets alive. We fed adult female copepods on freeze-thawed diatoms (Cylindrotheca fusiformis and Chaetoceros sp.) which had been colonized by natural populations of seawater bacteria labeled with ${ }^{3} \mathrm{H}$-leucine. The copepods retained 26 to $31 \%$ of the label $43 \mathrm{~h}$ after ingestion and subsequent gut clearance, indicating that a substantial fraction of bacterial biomass bound to particulates of appropriate size can be directly available to this copepod as a source of material and energy. Bacteria were present at very high concentrations $\left(10^{9}\right.$ to $\left.10^{10} \mathrm{ml}^{-1}\right)$ in the fecal pellets of copepod fed on bacterized food, but were absent in the fecal pellets of copepods fed axenic food. When fecal pellets freshly ejected by copepods fed bacterized food were incubated in seawater, bacteria abundances in them increased, yielding minimum specific growth rates of $0.08 \mathrm{~h}^{-1}$ (generation time $g=8.7 \mathrm{~h}$ ) at $16^{\circ} \mathrm{C}$ and 0.19 and $0.20 \mathrm{~h}^{-1}(g=3.6$ and $3.5 \mathrm{~h})$ at $22^{\circ} \mathrm{C}$. Since bacteria grew within the fecal pellets, at least some of the bacteria we found in the freshly egested fecal pellets must have survived gut passage. In order to determine whether bacteria imparted aminopeptidase activity to copepod fecal pellets, the enzyme activity of fecal pellets produced on uncolonized and colonized freeze-thawed diatoms was compared. This comparison showed that bacteria in the fecal pellets account for 68 to $84 \%$ of the aminopeptidase activity of fecal pellets, indicating a potential role for the interior bacteria in fecal pellet solubilization and fragmentation. We conclude that feeding of these copepods on attached bacteria not only serves to link the microbial loop with the grazing food chain but, because of the passage of viable bacteria into the fecal pellet, may also influence fecal pellet degradation.
\end{abstract}

\section{INTRODUCTION}

Bacteria associated with particles are generally 10 to $20 \%$ of the total bacterial population in seawater. Some bacteria may also occur associated with the polymer matrix and agglomorates in seawater (Azam \& Smith 1991, Alldredge et al. in press). Attached bacteria may thus be a substantial food source which, if passed on directly to metazoans, could link the microbial loop (Azam et al. 1983) with the grazing food chain. This direct pathway would likely be more important in waters with high particle load such as estuaries and coastal waters, and during post-algal bloom periods where the quantitative significance of produc- tion of attached bacteria can be quite high (Bell \& Albright 1981). Attached bacteria may also provide a mechanism of energy flow in oligotrophic waters where the primary production is often dominated by picoplankton too small to be efficiently ingested by metazoa and where bacterial carbon can exceed phytoplankton carbon (Fuhrman et al. 1989, Cho \& Azam 1990). Thus, attached bacteria are potentially an important pathway for energy and material to metazoa (Crocker et al. 1991, King et al. 1991) in waters of varied trophic status from highly oligotrophic to highly eutrophic.

An obvious prerequisite for this trophic link is that the dominant metazoa in the pelagic ocean, such as 
calanoid copepods, should be able to digest the ingested attached bacteria. The digestibility of bacteria is also of interest from the standpoint of the survival strategies of attached bacteria (Pedrós-Alió \& Brock 1983, Hoppe 1984) and the role of bacteria in fecal pellet decomposition (Jacobsen \& Azam 1984). Literature on both autotrophic (Johnson et al. 1982) and heterotrophic (Gowing \& Wishner 1986) bacteria suggests that copepods do not digest bacteria and therefore attached bacteria would not be an energy source for the copepods. If the ingested attached bacteria survive gut passage and thrive in fecal pellets then attachment to particles may actually be a survival strategy of bacteria (Hastings \& Nealson 1977, Andrews et al. 1984). Also, the bacteria passing into the fecal pellets may solubilize the particulate organic matter (POM) into dissolved organic matter (DOM) with their ectohydrolases. They may thereby increase the rate of degradation of tecal peilets. So, the fate of the attached bacteria ingested by copepods has implications for carbon flow pathways, bacterial survival and fecal pellet decomposition.

The purpose of the prosent study was to address 3 inter-related questions: (1) Is a significant fraction of the biomass of ingested bacteria assimilated by the pelagic marine copepod Calanus pacificus? (2) Does a substantial fraction of the bacterial population survive gut passage? If so, can they proliferate in the interior of the fecal pellet? (3) Do the egested bacteria impart hydrolytic enzyme activity to the fecal pellets of $C$. pacificus?

\section{METHODS AND MATERIALS}

Collection and maintenance of Calanus pacificus. Adult female $C$. pacificus were segregated from nettow catches from La Jolla Canyon, California $\left(32^{\circ} \mathrm{N}\right.$, $117^{\circ} \mathrm{W}$ ), from February to August 1991. They were kept in seawater filtered through $20 \mu \mathrm{m}$ Nitex ${ }^{\oplus}$ in allglass aquaria at $16^{\circ} \mathrm{C}$ and fed a mixture of dinoflagellates (principally Gyrodinium dorsum and Peridinium trochoideum) to satiation every 1 or $2 \mathrm{~d}$. Dead copepods and fecal pellets were regularly removed. Seawater in the aquaria was changed about once per week. C. pacificus used in field experiments (below) were obtained from the Santa Monica Basin in September 1991 by towing a $1 \mathrm{~m}$ diameter zooplankton net ( $330 \mu \mathrm{m}$ mesh) for $5 \mathrm{~min}$ through a 40 to $50 \mathrm{~m}$ depth interval.

Preparation of colonized frozen/thawed diatoms. The diatoms Cylindrotheca fusiformis (clone 7) and a Chaetoceros sp. (kindly provided by Dr B. E. Volcani, Scripps Institution) were grown axenically in an artificial sea water medium (T-20 medium; Kates \& Volcani 1966) to stationary phase at $\sim 100 \mu \mathrm{E} \mathrm{m}^{-2} \mathrm{~s}^{-1}$ at room temperature $\left(20\right.$ to $\left.22^{\circ} \mathrm{C}\right)$. The diatoms were sedimented $\left(1600 \times g_{i} 3 \mathrm{~min}\right)$, washed $2 \times$ in $5 \mathrm{ml}$ artificial sea water (ESAW; Harrison et al. 1980) and resuspended in $1 \mathrm{ml}$ ESAW. The cell concentrates were frozen in 2-propanol/dry ice and thawed at $60^{\circ} \mathrm{C}$ ( $<1 \mathrm{~min}$ ), and stored at $-20^{\circ} \mathrm{C}$. In Expts 1 and 2 (below) the diatoms were subjected to 1 freeze-thaw cycle while in Expt 3 they were subjected to 7 cycles. To obtain colonized freeze-thawed $(\mathrm{F} / \mathrm{T})$ diatoms, natural assemblages of bacteria were first grown in a 'seawater culture' (Ammerman et al. 1984). Ten $\mathrm{ml}$ seawater filtered through a $0.6 \mu \mathrm{m}$ polycarbonate filter (Nuclepore $\left.{ }^{3}\right)$ was added as inoculum into $90 \mathrm{ml} 0.22 \mu \mathrm{m}$ filtered (Millipore ${ }^{B}$ ) seawater and incubated for $24 \mathrm{~h}$. F/T diatoms (to $1-2 \times 10^{5} \mathrm{ml}^{-1}$, final concentration) were added to this presumably mixed culture of marine bacteria and incubated for 36 to $48 \mathrm{~h}$ during which the F/T diatoms became colonized by bacteria. Some large aggregates of colonized diatom detritus formed which were removed by filtering on $35 \mu \mathrm{m}$ Nitex $^{(k)}$ net. The $35 \mu \mathrm{m}$ filtrate was used in experiments where unlabeled colonized diatoms were fed to the copepods.

${ }^{3} \mathrm{H}$ labeling. In order to obtain $\mathrm{F} / \mathrm{T}$ diatoms colonized with ${ }^{3} \mathrm{H}$ labeled bacteria (for use in experiments to study the fate of the label) seawater cultures, grown as above, were labeled by incubating them with $20 \mathrm{nM}$ ${ }^{3} \mathrm{H}$-leucine (specific activity $155 \mathrm{Ci} \mathrm{mmol}{ }^{-1}$; New England Nuclear, Boston, MA) at $16^{\circ} \mathrm{C}$ for $24 \mathrm{~h}$. The labeled bacteria were then mixed with $\mathrm{F} / \mathrm{T}$ diatoms and allowed to colonize for 24 to $48 \mathrm{~h}$. This resulted in heavily colonized diatom detritus and aggregates in which only bacteria would be labeled. We calculated cell-specific ${ }^{3} \mathrm{H}$ labelling as counts per minute (CPM) bacterium $^{-1}$ in the mixture (Table 1) from bacterial counts (epifluorescence microscopy, below) and radioassay. Just before offering the labeled food to the copepods, the suspension was filtered through $35 \mu \mathrm{m}$ Nitex ${ }^{\circledR}$ to eliminate large aggregates, collected on $5 \mu \mathrm{m}$ Nitex ${ }^{\otimes}$ to remove free bacteria, and washed several times with filter sterilized ESAW to remove the unincorporated ${ }^{3} \mathrm{H}$-leucine. The particles were then

Table 1. Composition and ${ }^{3} \mathrm{H}$ contents of the labeled colonized food fed to Calanus pacificus. F/T: freeze-thawed; diatom: Chaetoceros sp; CPM: counts per minute

\begin{tabular}{|c|c|c|c|}
\hline & Expt 1 & Expt 2 & Expt 3 \\
\hline $\mathrm{F} / \mathrm{T}$ diatom $\mathrm{ml}^{-1}$ & $3.4 \times 1.0^{5}$ & $4.0 \times 10^{3}$ & $2.4 \times 10^{5}$ \\
\hline Live diatom $\mathrm{ml}^{-1}$ & $1.0 \times 10^{4}$ & $6.2 \times 10^{3}$ & $6.2 \times 10^{3}$ \\
\hline Attached bacteria $\mathrm{ml}^{-1}$ & $9.5 \times 10^{5}$ & $7.8 \times 10^{5}$ & $1.1 \times 10^{6}$ \\
\hline $\begin{array}{l}\text { Attached bacteria } \\
(\mathrm{F} / \mathrm{T} \text { diatom })^{-1}\end{array}$ & 2.7 & 76.1 & 4.6 \\
\hline CPM bacterium $^{-1}$ & 0.013 & 0.019 & 0.012 \\
\hline
\end{tabular}


resuspended in ESAW to achieve the desired diatom concentration (Table 1). Approximately $10^{4} \mathrm{ml}^{-1}$ live diatom cells were added to the suspension shortly before use since this increased the ingestion rate.

To ascertain that F/T diatoms did not take up measurable ${ }^{3} \mathrm{H}$-leucine during the labeling an $\mathrm{F} / \mathrm{T}$ diatom suspension alone (no bacteria) was incubated with $20 \mathrm{nM}^{3} \mathrm{H}$-leucine for $48 \mathrm{~h}$, filtered onto a $0.45 \mu \mathrm{m}$ filter, washed and radioassayed. We found that $\mathrm{F} / \mathrm{T}$ diatoms did not take up measurable ${ }^{3} \mathrm{H}$.

Ingestion of ${ }^{3} \mathrm{H}$-labeled bacteria and the fate of the ingested ${ }^{3} \mathrm{H}$. Adult female copepods were allowed to feed on the ${ }^{3} \mathrm{H}$ labeled suspension (above) for $0.5 \mathrm{~h}$. Six to ten copepods were destructively radioassayed to determine the label ingested. The remaining copepods were rinsed $2 \times$ with $50 \mathrm{ml}$ ESAW and immediately transferred to unlabeled F/T diatom suspension and allowed to feed for 0.5 to $2 \mathrm{~h}$ to clear their guts of the unassimilated labeled food. Again, 6 to 10 copepods were destructively radioassayed to determine the label remaining in the animals' tissue after gut clearing (assimilation). The remaining copepods were rinsed in ESAW and placed in a second aliquot of unlabeled F/T diatom suspension, and the process was repeated at several time points. This protocol enabled us to determine the decrease with time of the label which the copepod had assimilated during the $0.5 \mathrm{~h}$ feeding on ${ }^{3} \mathrm{H}$ labeled food while minimizing reingestion of excreted or egested label (since we moved the copepods to new suspensions of unlabeled food). We also measured the label in all the fecal pellets egested during a given period. In order to obtain a complete accounting of the label ingested by the copepods we also radioassayed: (1) $1 \mathrm{ml}$ aliquots of the water used for rinsing the copepods before transferring them to a suspension of unlabeled food, and (2) $1 \mathrm{ml}$ aliquots of the food suspension in which the copepods had been feeding but from which the fecal pellets had been removed. This was intended to be a measure of respiratory losses of ${ }^{3} \mathrm{H}_{2} \mathrm{O}$ as well as any label lost via DOM excretion by the copepods. We expected that the label lost from the copepods for a given time period would equal the sum of the label in the fecal pellets, feeding suspension and the rinse water.

Samples were radioassayed by liquid scintillation spectrometry in Ecoscint ${ }^{\otimes}$ (National Diagnostics) as fluor. Copepods and fecal pellets were digested with $5 \mathrm{~N} \mathrm{HCl}$ at $100^{\circ} \mathrm{C}$ for $15 \mathrm{~min}$ before adding the fluor.

Microscopy. Fecal pellet dimensions were measured microscopically using a calibrated grid, and their volumes were calculated by assuming that they were cylindrical. Bacteria were counted by epifluorescence microscopy of samples stained with 4,6-diamidino-2phenylindole (DAPI; Porter \& Feig 1980). In order to count bacteria in the fecal pellets it was necessary to first release them from the pellets. Fecal pellets were preserved in $2 \%$ buffered formaldehyde for $20 \mathrm{~min}$ to $2 \mathrm{~h}$. They were treated with $0.01 \%$ Tween-80 (polyoxyethylene (20) sorbitan monooleate) and $10 \mu \mathrm{g} \mathrm{ml}^{-1}$ DAPI (final concentrations) for 20 to $30 \mathrm{~min}$ and sonicated for $15 \mathrm{~s}$ (Yoon \& Rosson 1990). This procedure released and dispersed the bacteria. The samples were then enumerated by epifluorescence microscopy. Diatoms were observed by their autofluorescence

Bacterial abundance and production in fecal pellets. Growth rates of bacteria in the fecal pellets were determined on the basis of increase in bacterial abundances with time. This approach was adopted because of its simplicity and directness but it could underestimate bacterial growth if significant bacterial mortality occurred during incubations. We did not detect protozoa in fecal pellets, but other potential causes of bacterial mortality (e.g. bacteriophage attack and autolysis) were not examined. Our production estimates may therefore be conservative. Specific growth rates $(\mu)$ and generation time $(g)$ were calculated.

Bacterial abundance and growth were measured in fecal pellets of Calanus pacificus fed: (1) live diatoms, (2) live diatoms plus bacteria, (3) F/T diatoms, (4) F/T diatoms plus bacteria, and (5) food particles contained in $35 \mu \mathrm{m}$-filtered flowing seawater (fed to copepods caught in the field in Santa Monica Basin). Fecal pellets were recovered by washing them onto $35 \mu \mathrm{m}$ Nitex $^{\circledR}$ with 4 to $6(10$ to $50 \mathrm{ml})$ aliquots of $0.2 \mu \mathrm{m}$ filtered ESAW. They were then used for bacterial counts or incubated for measuring bacterial growth in the fecal pellets. An aliquot was stained with DAPI and examined microscopically to ensure the exterior surfaces were free of attached bacteria.

Calanus pacificus captured in the field (no. 5, above) may have been feeding on concentrated particulate matter during collection and sorting. We allowed them to empty their guts and let them feed on 'natural' food in the size range suitabie for copepod feeding (Huntley et al. 1983). After collection and sorting, the copepods were kept for $2 \mathrm{~d}$ in an aquarium through which seawater filtered through $35 \mu \mathrm{m}$ Nitex ${ }^{\otimes}$ was running. After clearing the aquarium of all particulate matter the copepods were returned, the $35 \mu \mathrm{m}$ filtered seawater inflow was resumed, and the copepods were allowed to produce fecal pellets for $45 \mathrm{~min}$. The fecal pellets were immediately collected and fixed for bacteria counts or incubated for growth rate experiments.

Aminopeptidase activity. Aminopeptidase activity was measured as increase in fluorescence as the substrate L-leucine 7-amino-4-methyl-coumarin (leuAMC; Sigma) was hydrolyzed to the highly fluorescent product 7-amido-4-methyl-coumarin (AMC) (Hoppe 1983). The substrate was added at $20 \mu \mathrm{M}$ to washed fecal pellets or seawater samples (where the amino- 
Table 2. Calanus pacificus. Mean dimensions $(\mu \mathrm{m})$ and volumes $\left(10^{6} \mu \mathrm{m}^{3}\right)( \pm \mathrm{SD}$ ) of pellets formed by copepods feeding on $\mathrm{F} / \mathrm{T}$ Chaetoceros sp. alone or on F/T Chaetoceros sp. colonized with bacteria. n: no of fecal pellets examined; diatom: Chaetoceros $\mathrm{sp}$

\begin{tabular}{|lcccc|}
\hline & $\mathrm{n}$ & Length & Diameter & Volume \\
\hline F/T diatom & 59 & $426.7 \pm 192.7$ & $71.2 \pm 14.9$ & $1.88 \pm 1.24$ \\
F/T diatom + bacteria & 63 & $392.5 \pm 209.3$ & $76.0 \pm 18.0$ & $1.85 \pm 1.51$ \\
\hline
\end{tabular}

Table 3. Bacterial abundance in Calanus pacificus fecal pellets under 3 different feeding conditions. Colonized diatoms: the copepods were fed on freeze-thawed Chaetoceros $\mathrm{sp} .\left(1.6 \times 10^{4}\right.$ cells $\left.\mathrm{ml}^{-1}\right)$ which had $3.1 \times 10^{5}$ attached bacteria $\mathrm{ml}^{-1}$. Freshly caught copepods: the copepods were in the presence of concentrated particle suspension during net tow and sorting which took 0.25 to $0.75 \mathrm{~h}$; FP: fecal pellet. $35 \mu \mathrm{m}$ filtered flowing seawater: copepods were kept in $35 \mu \mathrm{m}$ Nitex filtered flowing seawater from Santa Monica Basin

\begin{tabular}{|lccc|}
\hline Feeding conditions & $\begin{array}{c}\text { Duration } \\
(\mathrm{h})\end{array}$ & $\begin{array}{c}\text { Bacteria FP-1 } \\
\left(\times 10^{4}\right)\end{array}$ & $\begin{array}{c}\text { Bacteria ml }^{-1} \mathrm{FP}^{-1} \\
\left(\times 10^{9}\right)\end{array}$ \\
\hline $\begin{array}{l}\text { Fod colonized diatoms } \\
\text { Freshly caught animals }\end{array}$ & 3.5 & 1.3 & 7.0 \\
$35 \mu \mathrm{m}$ filtered flowing seawater & $0.25-0.75$ & 0.75 & $3.9-18.9$ \\
& 0.6 & 8.6 \\
\hline
\end{tabular}

peptidase activity was also measured to provide a comparison with the per-cell and per-volume aminopeptidase activity in the fecal pellets). AMC fluorescence was measured in a filter fluorometer (Hoefer; excitation $365 \mathrm{~nm}$, emission $465 \mathrm{~nm}$ ).

\section{RESULTS}

\section{Bacterial abundance and production}

Table 2 shows that the dimensions of the fecal pellets were comparable whether the copepods were fed on uncolonized or colonized F/T diatoms. We could not detect any bacteria in fecal pellets produced by copepods feeding on axenic $\mathrm{F} / \mathrm{T}$ diatoms. As shown in Table 3, copepods fed colonized F/T diatoms or natural marine particulates produced fecal pellets which contained high concentrations of bacteria. The bacteria] abundance ( 7.2 to $35 \times 10^{3}$ per fecal pellet) when normalized to the fecal pellet volume $(1.85 \mathrm{nl})$ yields bacterial concentrations of $3.9 \times 10^{9}$ to $1.89 \times 10^{10} \mathrm{ml}^{-1}$ What fraction of these bacteria were viable could not be determined. We note, however, that the generation. times, calculated by assuming that all bacteria were viable, were as low as $3.5 \mathrm{~h}$ (Table 4). Minimum estimates of bacterial carbon production, based on cell accumulation with time, were 1.4 to $6.7 \mathrm{ng} C$ (fecal pellet) ${ }^{-1} \mathrm{~d}^{-1}$ (assuming that each new-born bacterium contained $20 \mathrm{fg} \mathrm{C}_{i}$ Lee \& Fuhrman 1987; we also assume that all bacteria were intact and hence contained their complete complement of carbon).

\section{Aminopeptidase activity}

Intense aminopeptidase activity was found in the fecal pellets whether they had been produced on axenic food or bacterized food (Table 5). The fecal pellets had $10^{4}$ times higher aminopeptidase activity than an equivalent volume of seawater. The activity in the axenic pellets was probably due to residual digestive aminopeptidase; F/T Chaetoceros sp. would be the other probable candidate but it did not contain measurable aminopeptidase activity (not shown). However, the fecal pellets produced on bacterized food had 3- to 5 -fold higher activity than those produced on axenic food (Table 5). The additional activity is probably due to the presence of bacteria in the fecal pellets. However, we cannot exciude the possibility that when

Table 4. Abundances, specific growth rates $(\mu)$ and generation times $(g)$ of bacteria in Calanus pacificus fecal pellets. The copepods were freshly caught by a net tow in Santa Monica Basin, they may have been feeding on net tow material during capture and sorting $(0.25$ to $0.75 \mathrm{~h})$. Incubation temperature was $16^{\circ} \mathrm{C}$ in Expt 1 and $22^{\circ} \mathrm{C}$ in Expts 2 and 3 FP: fecal pellet; $N_{0}$ and $N_{i}$ : no. of bacteria at beginning and end of incubation

\begin{tabular}{cccccc|}
\hline Expt & $\begin{array}{c}\text { Incubation } \\
\text { period } \\
(\mathrm{h})\end{array}$ & $\begin{array}{c}\text { Bacteria FP-1 } \\
\left(\times 10^{4}\right)\end{array}$ & $\mu$ & $g$ \\
$N_{0}$ & $N_{t}$ & $\left(\mathrm{~h}^{-1}\right)$ & $(\mathrm{h})$ \\
\hline 1 & 12 & 3.5 & 8.8 & 0.08 & 8.7 \\
2 & 7.25 & 0.72 & 2.9 & 0.19 & 3.6 \\
3 & 8 & 2.9 & 14 & 0.2 & 3.5 \\
\hline
\end{tabular}


Table 5. Aminopeptidase activity in seawater and in fecal pellets of Calanus pacificus. Aminopeptidase activity was measured as the rate of hydrolysis of L-leucine 7-amino-4-methyl-coumarin (leu-AMC). Seawater samples were taken from the end of Scripps Pier and fecal pellets from copepods maintained in the laboratory. SW: seawater; FP: fecal pellets; VCF: volume concentration factor (activity in fecal pellets divided by activity in an equal volume of seawater); NA: not applicable (since no bacteria were present)

\begin{tabular}{|c|c|c|c|}
\hline \multirow[t]{2}{*}{ Sample } & \multicolumn{2}{|c|}{ Leu-AMC hydrolysis } & \multirow[t]{2}{*}{ VCF (average) } \\
\hline & $\mu \mathrm{mol} \mathrm{ml} l^{-1} \mathrm{~d}^{-1}$ & amol bact. ${ }^{1} \mathrm{~d}^{-1}$ & \\
\hline SW (whole) & $1.82 \times 10^{-4}$ & 96 & - \\
\hline SW (0.6 $\mu \mathrm{m}$ filtered) & $0.75 \times 10^{-4}$ & 58 & - \\
\hline SW $(0.2 \mu \mathrm{m}$ filtered $)$ & Undetectable & NA & - \\
\hline FP (on F/T Chaetoceros sp.) & $2.6-4.0$ & NA & $1.8 \times 10^{4}$ \\
\hline $\mathrm{FP}$ (on $\mathrm{F} / \mathrm{T}$ Chaetoceros sp. + bacteria) & $15.8-16.3$ & 1820 & $8.8 \times 10^{4}$ \\
\hline
\end{tabular}

Table 6. Calanus pacificus. Variability of uptake and retention of ${ }^{3} \mathrm{H}$ by copepods fed ${ }^{3} \mathrm{H}$-leucine-labeled bacteria. The data are from Expt 3 (see text) $\mathrm{n}=10$

\begin{tabular}{|ccc|}
\hline \multirow{2}{*}{$\begin{array}{c}\text { Sampling interval } \\
(\mathrm{h})\end{array}$} & \multicolumn{2}{c|}{ CPM copepod } \\
& Mean \pm SD & Range \\
\hline 0 & $1019.4 \pm 918.4$ & $209-2667$ \\
1 & $621.7 \pm 528.1$ & $94-1373$ \\
3 & $587.2 \pm 517.6$ & $74-1553$ \\
7 & $350.5 \pm 475.0$ & $47-1568$ \\
21.5 & $179.8 \pm 180.5$ & $24-568$ \\
27 & $279.0 \pm 503.5$ & $20-1301$ \\
\hline
\end{tabular}

the food contains bacteria the copepod secretes more aminopeptidase (or that a larger fraction of aminopeptidase activity survives in the fecal pellet when bacteria are present). Assuming the additional activity in bacterized fecal pellets to be due to bacteria, we calculate that the per-cell aminopeptidase in the fecal pellet was 19-fold the per-cell activity in seawater. tained a significant fraction of the ingested ${ }^{3} \mathrm{H}$ (average $17.3 \%$; range 10.2 to $22.0 \%$; Table 7 ). Little ${ }^{3} \mathrm{H}$ was released after the first sampling time point $(\sim 2 \mathrm{~h})$. One-half or more of the ingested ${ }^{3} \mathrm{H}$ was apparently released in solution (e.g. ${ }^{3} \mathrm{H}_{2} \mathrm{O}$ and labeled DOM) or suspended particles. As stated, the non-fecal release was calculated as: ${ }^{3} \mathrm{H}$ ingested $-\left({ }^{3} \mathrm{H}\right.$ assimilated $+{ }^{3} \mathrm{H}$ in the fecal pellets). The label found per fecal pellet was equivalent to between 2.8 and $12.0 \times 10^{3}$ bacteria per fecal pellet. In separate experiments (Table 3 ) microscopy showed bacterial abundance to be $1.3 \times 10^{4}$ per fecal pellet.

\section{DISCUSSION}

Digestibility of bacteria suggests that feeding of Calanus pacificus on attached bacteria can efficiently link the microbial loop with the grazing food chain. It is often implicitly assumed that copepods can digest bacteria but a direct demonstration had been lacking.

\section{Uptake and assimilation of bacterial biomass}

The ingestion of bacterial biomass by the individual copepods was highly variable in all 3 experiments and at each sampling interval the variability in one experiment is shown separately in Table 6 for clarity of presentation). However, trends with respect to uptake and depuration were similar in all 3 experiments (Fig. 1). After the copepods were transferred to unlabeled food their ${ }^{3} \mathrm{H}$ content dropped rapidly. The copepods had retained 26 to $31 \%$ of the ingested ${ }^{3} \mathrm{H}$ at $43 \mathrm{~h}$ after ingestion (Table 7). Following the transfer of the copepods into the unlabeled food, the early fecal pellets con-
Table 7. Calanus pacificus. Ingestion, assimilation and egestion of ${ }^{3} \mathrm{H}$-labeled bacteria. FP: fecal pellet; values in parentheses are time after ingestion (h)

\begin{tabular}{|c|c|c|c|}
\hline & \multicolumn{3}{|c|}{ Experiment No. } \\
\hline & 1 & 2 & 3 \\
\hline \multicolumn{4}{|l|}{ Ingested } \\
\hline CPM copepod ${ }^{-1}$ & 3307 & 568 & 1019 \\
\hline Bacteria equivalent & $2.5 \times 10^{5}$ & $3 \times 10^{4}$ & $8.5 \times 10^{4}$ \\
\hline \multicolumn{4}{|l|}{ Assimilated } \\
\hline CPM copepod $^{-1}$ & $868(43.2)$ & $174.5(18.2)$ & $279(27)$ \\
\hline Bacteria equivalent & $6.7 \times 10^{4}$ & $9.2 \times 10^{3}$ & $2.3 \times 10^{4}$ \\
\hline \multicolumn{4}{|l|}{ Egested in FP } \\
\hline CPM copepod ${ }^{-1}$ & 325 & 127 & 204 \\
\hline Bacteria equivalent & $2.5 \times 10^{4}$ & $6.7 \times 10^{3}$ & $1.7 \times 10^{4}$ \\
\hline \multicolumn{4}{|l|}{ Bacteria $\mathrm{FP}^{-1}$} \\
\hline Calculated from CPM & $1.2 \times 10^{4}$ & $2.8 \times 10^{3}$ & $4.6 \times 10^{3}$ \\
\hline
\end{tabular}




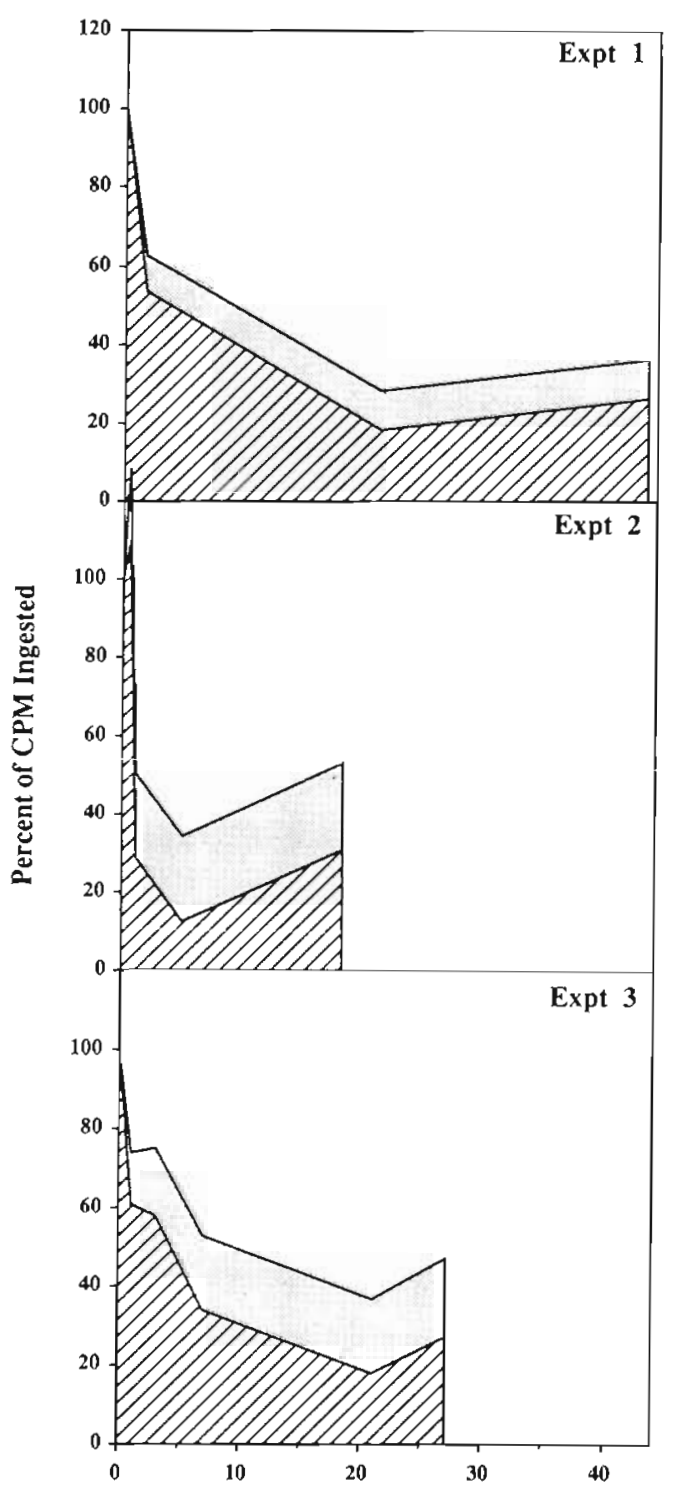

Time (hours)

Fig. 1 Retention and release of ${ }^{3} \mathrm{H}$ ingested by copepods. Results of 3 separate experiments are shown. ${ }^{3} \mathrm{H}$ ingested by the copepods fed ${ }^{3} \mathrm{H}$-labeled attached bacteria was measured and the per-animal ${ }^{3} \mathrm{H}$ (mean of 6 to 10 copepods) was treated as $100 \%$. At each subsequent time point the copepods were switched to unlabeled food and incubated for 0.5 to $2 \mathrm{~h}$ (during which time they lost part of the ingested ${ }^{3} \mathrm{H}$ via fecal pellets, respiration and excretion). "H remaining in the copepods (mean of 6 to $10 \mathrm{ind}$ ) or appearing in the fecal pellets was measured at each time point. "H per copepod remaining at various time points is plotted as $\%$ of the time zero value (lower curves). Cumulative " $\mathrm{H}$ in the fecal pellets (per individual) at various time points is plotted as $\%$ of ${ }^{3} \mathrm{H}$ in the copepods at time zero (shaded area). Other ${ }^{3} \mathrm{H}$ losses $[100-(\%$ in copepods + \% in fecal pellets)j ares presumably due to respiration as ${ }^{3} \mathrm{H}_{2} \mathrm{O}$ and release as ${ }^{3} \mathrm{H}$-D( M.1. Variahility of measurements was high and, for clarity of presentatıon, standard deviations and ranges are shown separately in Table 6 (for the data in Expt 3)
However, our study, while it shows that copepods can digest and assimilate bacterial biomass, has several limitations. We found that 26 to $31 \%$ of the ingested ${ }^{3} \mathrm{H}$ was assimilated (retained at $43 \mathrm{~h}$ ), but whether a similar fraction of ingested biomass or carbon was assimilated is not known. The specific activity of different cellular pools may have been different. ${ }^{3} \mathrm{H}$ leucine (which was used to label bacteria) predominantly labels protein in short incubations (Simon \& Azam 1989]. It may also have labeled other cellular pools in the long incubation ( 24 to $48 \mathrm{~h}$ ) used in this study, but this was not determined. Also, the efficiency of digestion of bacterial biomass may depend on what other food is simultaneously ingested in natural seawater. Despite these caveats, it appears that copepods can digest bacterial biomass or some part of the bacterial cells.

While a substantial fraction of the ingested bacterial biomass was digested some bacteria passed into the fecal pellets. DAPI staining showed the fecal pellets to have $1.30 \times 10^{4}$ bacteria per pellet (Table 3 ), while ${ }^{3} \mathrm{H}$ per fecal pellet was equivalent to between 0.28 and $1.20 \times 10^{4}$ bacteria (and represented 10.2 to $22.0 \%$ of the ingested label). The observed bacterial abundances, when normalized to the pellet volume, translate into very high concentrations $\left(10^{9}\right.$ to $\left.10^{10} \mathrm{ml}^{-1}\right)$. However, these bacterial abundances may have been an experimental artifact caused by feeding of the copepods on 'unnaturally' high food concentrations. We examined the fecal pellets of freshly caught animals, without feeding them, but these also had similarly high bacterial concentrations. We considered that freshly caught copepods may have fed on artifactually abundant food concentrations during the net tow and during the time it took to segregate the copepods. We therefore examined the fecal pellets of copepods which, immediately after being caught and segregated, were kept for $2 \mathrm{~d}$ in an aquarium with $35 \mu \mathrm{m}$ filtered flowing seawater (they were therefore considered to be feeding on natural concentrations of food). Their fecal pellets also had high bacterial concentrations similar to those in other treatments (Table 3). We therefore conclude that the high bacterial concentrations in the fecal pellets were not an experimental artifact. It appears that Calanus pacificus not only compacts phytoplankton remains and detritus but bacteria as well into its fecal pellets.

There are several reasons why we think that the bacteria we found in the fecal pellets were not enterics. Earlier studies did not find an enteric flora in Calanus pacificus (Honjo \& Roman 1978, Gowing \& Silver 1983. Jacobsen \& Azam 1984). Nott et al. (1985) suggest that Calanus hegolandicus, closely related to C. pacificus, does not harbor an enteric flora since the epithelium of the gut wall contributes the peritrophic membrane to 
the fecal pellet and since no bacteria were found in the empty guts of non-feeding copepods. While we did not directly check for the presence of an enteric flora, none was passed into the fecal pellets since copepods fed axenic food produced bacteria-free fecal pellets. We therefore think the bacteria egested into the fecal pellets were derived from the food.

Although the fraction of the viable egested bacteria was not determined, the population increased rapidly. As noted earlier, the assemblage generation times were as low as $3.5 \mathrm{~h}$ on the assumption that all egested bacteria were viable and growing. Such generation times are quite short for bacteria in natural samples. If only a fraction of the bacteria in the fecal pellet were viable and growing then the generation times would have been much shorter, which seems unlikely.

Bacteria which survived gut passage may have been resistant to the digestive enzymes of Calanus pacificus. Attached bacteria can have large amounts of surface proteoglycans and polysaccharides which may exceed the actual cell mass (Hobbie \& Lee 1980). The surface polymers may be resistant to the digestive enzymes and might also shield the bacterium. Alternatively, the surface polymers may actually be the part that is digested while the bacterium itself passes alive (i.e. the copepod enzymatically 'licks' polysaccharides off the bacterium). Resistance to digestion has previously been reported for freshwater bacteria by King et al. (1991) who showed that cultured freshwater bacteria survived ingestion by Daphnia ambigua. Attachment of bacteria to particles, then, may well be a survival strategy rather than a 'death wish'. Bacteria passing into fecal pellets proliferated rapidly, apparently at the expense of the nutrients in the fecal pellet. It has been hypothesized (Hastings \& Nealsen 1977. Andrews et al. 1984) that light production by particle-bound luminous bacteria is adaptive because it increases the chance that the particle along with the colonizers will be ingested by a visual predator and moved into the organically rich feces.

Despite their high abundance and rapid growth rates the carbon demand of bacteria in the fecal pellets was too low to cause rapid turnover of fecal carbon. We calculated the carbon demand by assuming $20 \mathrm{fg} \mathrm{C}$ per new cell (Lee \& Fuhrman 1987; dimensions of bacteria were not measured) and a carbon assimilation efficiency of $39 \%$ (Bjørnsen \& Kuparinen 1991). The range was 3.7 to $17 \mathrm{ng} \mathrm{C}$ per fecal pellet $\mathrm{d}^{-1}$ and at this rate the fecal pellet carbon [estimated to be $200 \mathrm{ng}$ per fecal pellet, assuming $1 \mu \mathrm{g}$ dry weight per fecal pellet (Azam unpubl.) and carbon content $=0.2 \times$ dry weight would take 11 to $54 \mathrm{~d}$ to turn over. A previous study (Jacobsen \& Azam 1984) used fecal pellets produced on axenic food and allowed them to be colonized in seawater. Their $C$ turnover time was even longer, on the order of
$10^{2}$ to $10^{3} \mathrm{~d}$. Possibly, the egestion of viable bacteria was responsible for the faster turnover rate in the present study. However, even at these comparatively rapid turnover rates the fecal pellet would sink out of the upper mixed layer before a large fraction of carbon could be utilized by bacteria, since the sinking rates of copepod fecal pellets are 10 to $100 \mathrm{~m} \mathrm{~d}^{-1}$ (Small et al. 1979) It is possible, however, that we had underestimated the bacterial carbon demand in the fecal pellets. We assumed bacterial carbon content to be $20 \mathrm{fg} \mathrm{cell}^{-1}$ but this might be an underestimate if the newly produced bacteria in the fecal pellets were larger than $0.07 \mu^{3}$ cell $^{-1}$ (Lee \& Fuhrman 1987). Simon et al. (1990) estimated that bacteria produced on marine snow had $70 \pm 24 \mathrm{fg} \mathrm{C}$ cell $^{-1}$ ( $\mathrm{n}=7$; one outlier was excluded). If we use $70 \mathrm{fg} \mathrm{C}$ cell $^{-1}$ (rather than $20 \mathrm{fg} \mathrm{C}$ cell-1) in our calculation of bacterial carbon demand this will lead to a proportionate decrease in the estimates of the turnover time of the fecal pellet carbon from 11-54 d (above) to 3.1-15.4 d.

The fecal pellets contained intense aminopeptidase activity, $10^{4}$ to $10^{5} \times$ greater than in an equal volume of seawater, in part because of the presence of high concentrations of bacteria in the fecal pellets. It would be interesting to determine if other ectohydrolase activities are also enhanced in fecal pellets and whether ectohydrolases cause 'uncoupled solubilization' of the fecal pellet organic matter (much faster hydrolytic solubilization than the uptake of the resulting DOM by bacteria) as has been reported for marine snow (Smith et al. 1992). High activities of bacterial ectohydrolases could play roles both in copepod digestion and in the fate of the fecal pellet. The ingested bacteria may also hydrolyze food components which the copepod cannot hydrolyze because it lacks the necessary enzymes. If so, then the attached bacteria would be used as proxies for a gut microflora and this role of the ingested bacteria would be more effective if the hydrolytic capabilities of attached bacteria match the particulate food of the copepod in the environment. The hydrolases could continue to 'digest' the fecal pellet.

Jumars et al. (1989) have postulated that fecal pellets $<1 \mathrm{~mm}$ diameter (such as those of Calanus pacificus) are stripped of DOM within seconds to minutes. Our results suggest that continued hydrolase activity could sustain the production of DOM from fecal POM. It is tempting to speculate that vertically migrating copepods may benefit by reingesting the bacteria-rich fecal pellets (Lampitt et al. 1990) which have been partially 'digested' by enzymes during their descent through the water column.

All 3 questions we posed have been answered in the affirmative: a significant fraction of the ingested bacterial biomass was digested and assimilated; some bacte- 
ria remained viable during gut passage and grew rapidly in the fecal pellets; and the ingestion of bacteria resulted in enhanced aminopeptidase activity in the fecal pellets. Thus, attached bacteria may play a role in copepod nutrition as well as in fecal pellet degradation. This study suggests that both the digestion and survival of the ingested bacteria can have significant implications for carbon flow pathways in the pelagic ocean. Particularly, the population and species dynamics of bacteria in the fecal pellets, and the ectohydrolase activities expressed by them, should be considered in future thinking about the mechanisms of fecal pellet decomposition in the ocean.

Acknowledgements. We thank D. C. Smith and G. F. Steward for critical review and helpful suggestions. Axenic diatom cultures of diatoms were kindly provided by Dr B. E. Volcani for which we are grateful. We thank Dr W. P. Cochlan for advice on culturing of diatoms, $J$. Lovette for supplying mixed aigai cultures and R. McConnaughey for collecting copepods throughout the study. We thank captain L. Zimm and the crew of RV 'Robert Gordon Sproul' for assistance at sea. This research was supported by US NSF and ONR grants to F.A. and by a term of Development Leave to S.G.L. by the Department of Fisheries and Ocean, Canada.

\section{LITERATURE CITED}

Alldredge, A. L., Passow, U., Logan, B. (in press). The existence, abundance and significance of large transparent exopolymer partıcles in the ocean. Deep Sea Res.

Ammerman, J. W., Fuhrman, J. A., Hagström, §., Azam, F. (1984). Bacterioplankton growth in seawater: I. Growth kinetics and cellular characteristics in seawater cultures. Mar. Ecol. Prog. Ser. 18: 31-39

Andrews, C. C., Karl, D. M., Small, L. S., Fowler, S. W. (1984). Metabolic activity and bioluminescence of oceanic faecal pellets and sediment trap particles. Nature 307: 539-541

Azam, F., Fenchel, T., Field, J. G., Gray, J. S., Meyer-Reil, L. A., Thingstad, F. (1983). The ecological role of watercolumn microbes in the sea. Mar. Ecol. Prog. Ser. 10: $257-263$

Azam, F., Smith, D. C. (1991). Bacterial influence on the variability in the ocean's biogeochmical state: a mechanistic view. In: Demers, S. (ed.) Particle analysis in oceanography. Springer-Verlag, Ber lin., p. 213-236

Bell, C. R., Albright, L. J (1981). Attached and free-floating bacteria in the Fraser River Estuary, British Columbia, Canada. Mar. Ecol. Prog. Ser. 6: 317-327

Bjørnsen, P. K., Kuparinen, J (1991). Determination of bacterioplankton biomass, net production and growth efficiency in the Southern Ocean. Mar. Ecol. Prog. Ser. 71: $185-194$

Cho, B. C., Azam, F. (1990). Biogeochemical significance of bacterial biomass in the ocean's euphotic zone. Mar. Ecol Prog. Ser. 63: 253-259

Crocker, K. M., Alldredge, A. L.. Steinberg, D. K. (1991) Feeding rates of the doliolid, Dolioletta gegenbauri, on diatoms and bacteria. J. Plankton Res. 13: 77-82

Fuhrman, J. A., Sleeter, T D., Carlson, C. A., Proctor, L. M.
(1989). Dominance of bacterial biomass in the Sargasso Sea and its ecological implications. Mar. Ecol. Prog. Ser 57: $207-217$

Gowing, M. M., Silver, M. W. (1983). Origins and microenvironments of bacteria mediating fecal pellet decomposition in the sea. Mar. Biol. 73: 7-16

Gowing, M. M., Wishner, K. F. (1986). Trophic relationships of deep-sea calanold copepods from the benthic boundary layer of the Santa Catalina Basin, California. Deep Sea Res. 33: 939-961

Harrison, P. J., Waters, R. E., Taylor, F. J. R. (1980). A broad spectrum artificial seawater medium for coastal and open ocean phytoplankton. J. Phycol. 16: 28-35

Hastings, J. W., Nealson, K. H. (1977). Bacterial bioluminescence. A. Rev. Microbiol. 31: 549-595

Hobbie, J. E., Lee, C. (1980). Microbial production of extracelIular material: importance in benthic ecology. In: Tenore, K. R., Coull, B. C. (eds.) Marine benthic dynamics. Univ. of South Carolina Press, Columbia, p. 341-346

Honjo, S., Roman, M. R. (1978). Marine copepod fecal pellets production, preservation and sedimentation. J. mar. Res. 36: $45-57$

Hoppe, H.-G. (1983). Significance of exoenzymatic activities in the ecology of brackish water: measurements by means of methylumbelliferyl-substrates. Mar. EcoI. Prog. Ser. 11 $299-308$

Hoppe, H.-G. (1984). Attachment of bacteria: advantage or disadvantage for survival in the aquatic environment. In Marshall, K. C. (ed.) Microbial adhesion and aggregation. Springer-Verlag, New York, p. 283-301

Huntley, M. E., Barthel, K.-G., Star, J. L. (1983). Particle rejection by Calanus pacificus: discrimination between similarly sized particles. Mar. Biol. 74: 151-160

Jacobsen, T R., Azam. F. (1984). Role of bacteria in copepod fecal pellet decomposition: colonization, growth rates and mineralization. Bull. mar. Sci. 35: 495-502

Johnson, P. W., Xu, H.-S., Sieburth, J. McN. (1982). The utilization of chroococcoid cyanobacteria by marine protozooplankters but not by calanoid copepods. Annls Inst. océanogr., Paris 58: 297-308

Jumars, P. A., Penry, D. L., Baross, J. A., Perry, M. J., Frost, B W. (1989). Closing the microbial loop: dissolved carbon pathway to heterotrophic bacteria from incomplete ingestion, digestion and absorption in animals. Deep Sea Res 36: $483-495$

Kates, M., Volcani, B. E. (1966). Lipid components of diatoms Biochem. biophys. Acta 116: 264-278

King, C. H., Sanders, R. W., Shotts, E. B., Porter, K. G. (1991). Differential survival of bacteria ingested by zooplankton from a stratified eutrophic lake. Limnol. Oceanogr. 36: $829-845$

Lampitt, R. S., Noji, T, von Bodungen, B. (1990). What happens to zooplankton faecal pellets? Implications for material flux. Mar. Biol. 104: 15-23

Lee, S., Fuhrman, J. A. (1987). Relationships between biovolume and biomass of naturally derived marine bacterioplankton. Appl. envir. Microbiol. 53: 1298-1303

Nott, J. A., Corner, E. D. S., Mavin, L. J., O'Hara, S. C. M. (1985). Cyclical contributions of the digestive epithelium to faecal pellet formation by the copepod Calanus helgolandicus. Mar. Biol. 89: 271-279

Pedrós-Alió, C., Brock, T D. (1983). The importance of attachment to particles for planktonic bacteria. Arch. Hydrobiol. 98: $354-379$

Porter, K. G., Feig, Y S. (1980). The use of DAPI for identifying and counting aquatic microflora. Limnol. Oceanogr. 25: $943-948$ 
Simon, M., Alldredge, A. L., Azam, F. (1990). Bacterial carbon dynamics on marine snow. Mar. Ecol. Prog. Ser. 65: 205-211

Simon, M. Azam, F. (1989). Protein content and protein synthesis rates of planktonic marine bacteria. Mar. Ecol. Prog. Ser. 51: 201-213

Small, L. F., Fowler, S. W., Ünlü, M. Y. (1979). Sinking rates of natural copepod fecal pellets. Mar Biol. 51: $233-241$

This article was presented by N. D. Holland, La Jolla, California, USA
Smith, D. C., Simon, M., Alldredge, A. L., Azam, F. (1992). Intense hydrolytic enzyme activity on marine aggregates and implications for rapid particle dissolution. Nature 359 $139-142$

Yoon, W. B., Rosson, R. A. (1990). Improved method of enumeration of attached bacteria for study of fluctuation in the abundance of attached and free-living bacteria in response to diel variation in seawater turbidity. Appl. environ. Microbiol. 56: 595-600

Manuscript first received: December 4, 1992 Revised version accepted: February 22, 1993 